\title{
Communication Channel Between Teachers and Students in Chemistry Education: WhatsApp
}

\author{
Nuray ZAN \\ Çankiri Karatekin University, Çankiri, Turkey
}

WhatsApp is a smartphone application used for instant messaging. It has been popular in the community in recent years, but it also has been used in education. In the field of education, there are studies related to field-specific subjects in English and chemistry education related to the use of WhatsApp during school hours and outside of school time. However, there could not be reached any study investigating how a specific field teacher and students use this application in voluntary groups without being bound to a particular program. For this purpose, semi-structured interviews were conducted with chemistry teachers by using WhatsApp application to communicate with students. A study was conducted with eight volunteer chemistry teachers working in State Anatolian High Schools in Çankiri and Ankara provinces. In this study conducted with the teachers at high school level, it was found out that WhatsApp application is used for five main purposes: First, these are increasing the students' motivation for the course, strengthening the communication, encouraging information sharing among students, using as an opportunity to learn, and planning the study process. The messages that accelerate the tempo of study to increase the motivation of the students about the course, sending clues about the content of the course, expressions that make them feel the success, messages indicating that their identity and personalities are valuable, the photographs of the moments experienced together were evaluated within the first scope. Second were the messages, to strengthen communication, celebrating special days and achievements, and increasing the sense of belonging. Third, information sharing content was composed of audio record, problem, solution of the problem, visuals, and documents related to a subject. Fourth, instant answers given about an unclear topic, related questions and answers were discussed in the opportunity to learn category. Finally, reminding the deadline for projects and assignments, time for exam preparation. Giving feedback were evaluated within the process planning. In addition, the learning outcomes offered by WhatsApp which is easy to use and a low-cost communication channel can be added as an advantage. Besides, providing easy access to learning materials outside the classroom, recording a speech easily, and transmitting the recording to everyone concurrently were stated as positive opinions. On the other hand, teachers indicated that there are disadvantages of the application. Teachers stated that it would be difficult to use the application in a group of students with no smartphone or Internet connection and it would not be fair in terms of communication. The teachers also stated that their motivation decreases when the students are unconcerned about questions asked by the teachers. In addition, the lack of appropriate language in communication among students in the group, in which the teacher is involved, creates educational difficulty in practice. Because of such student attitudes, the teachers are moving away from the practice by stopping the messages.

Keywords: chemistry education, WhatsApp, social network, instant message, communication

Nuray ZAN, Dr., association professor, Department of Educational Sciences, Faculty of Art, Çankiri Karatekin University. 


\section{Introduction}

More than one billion people in more than 180 countries are using the WhatsApp application to communicate anytime and anywhere. WhatsApp offers an easy, secure, reliable messaging, and search service that can be used for free (data charges can be charged) with telephones all around the world (Whatsapp, 2017). WhatsApp, launched in 2010, is a smartphone application that works on all current devices and operating systems.

WhatsApp application is used to send and receive messages to individuals or groups. Up to $100 \mathrm{MB}$ text messages, visuals, audio files, video files, PDF, documents, spreadsheets, slideshows, and more can be delivered (Whatsapp, 2017). Also, the links to Web addresses are shared via this application (Dan Bouhnik \& Deshen, 2014). The WhatsApp application can be defined as a social network allowing quick access to information. The simplicity of its use allows it to be preferred by people of all ages. The WhatsApp provides communication opportunity for anyone who installed the application on a smartphone with Internet connection. An important feature of the application is the ability to create a group and to communicate only with the people in the group. The person creating the group becomes the admin of the group and has the right to add and remove new members without the approval of the group members. Except for the admin, all members have equal rights. A warning tone is heard for each message and the user can silence these alerts for a certain period of time.

The aim of this study is to investigate the communication between the chemistry/chemistry technology teachers working in high schools and their students through WhatsApp. A study was conducted with eight volunter chemistry teachers working in State Anatolian High Schools in Çankiri and Ankara provinces. Semi-structured interviews were conducted with chemistry teachers by using WhatsApp application to communicate with their students. In the study, while determining the chemistry teachers communication goals, it was found out that different purposes are also served by using the WhatsApp application. Although the experiences of the interviewed chemistry teachers about WhatsApp, which they use as educational tools, belong to only one academic year, the results of this research show that the WhatsApp application can be an important potential in the field of education.

\section{Literature Review}

This section contains the previous researches carried out in the field of education on the instant messaging through the WhatsApp application.

To support formal education, educators can use applications, such as WhatsApp for creating a discussion environment with students and distributing and sharing content (Conejar \& Kim, 2014). Nowadays, because of the frequent use of Internet by students, e-learning, Web-based learning, and social media-supported learning concepts and practices are becoming widespread in education. Moreover, enriching the shares with materials, such as text, audio, and video supports teachers' teaching and evaluation of students while contributing to the learning process of students (Jones, Blackey, Fitzgibbon, \& Chew, 2010; Goodyear, Banks, Hodgson, \& McConnell, 2004).

As well as the advantages of social media-supported education, there are also some disadvantages. In some studies, it was stated that social media distracts the students' attention, causes students to allocate less time on the courses, and the academic achievement to decrease (Kulesza, DeHondt, \& Nezlek, 2011; Kirschner \& Karpinski, 2010). 
N. Zan, B. Zan, and Morgil (2014) taught the nomenclature of the compounds topic in chemistry education to the 9th grades supported by WhatsApp and received successful results. A study was carried out by Zan in 2015 with 12th grade students on the nomenclature of organic compounds with the support of Whatsapp.

Foreign language learning was studied in a study titled "What is happening in the classroom with mobile learning?” by Santarosa and Castillo (2017), and the first message sent by the teacher when the group was established was "the rules" (see Figure 1).

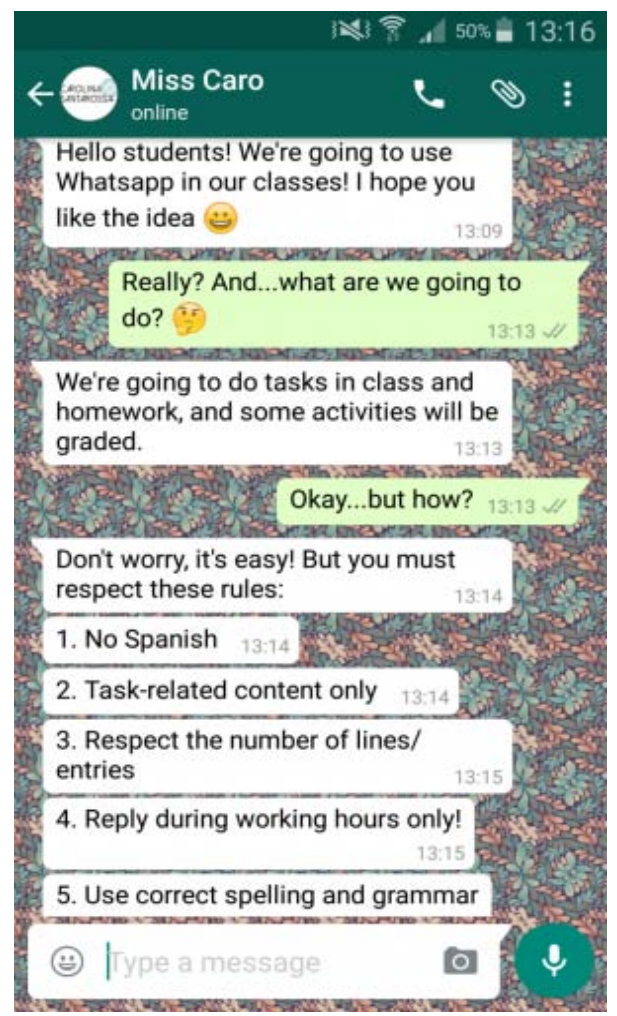

Figure 1. The rules sent in the study by Santarosa and Castillo (2017).

In the field of health, the research conducted by Turaç, Çalişkan, and Gülnar in 2017 compared the effects of full learning model and WhatsApp supported teaching on psychomotor skill teaching and suggested that social media should be used supportively for other education studies.

The fact that thousands of students who participated in the support and training courses organized for high school students in official formal and non-formal education institutions affiliated to the Ministry of National Education (MNE) have chosen the mathematics course prompted the Research and Development Department of Manisa of MNE. The project called "e-mathematics" aims training on WhatsApp and expects high school students to start using their smartphones for training (Whatsapp Period in Education, 2017). WhatsApp has entered the education system as a new application. The various current features and the easy of use of the WhatsApp application enhances the use of teachers and students. While this research was conducted among high school chemistry teachers, a significant part of the above mentioned studies were conducted at higher education levels.

The comparison of social media and instant messaging tools available in the field of education is described in Table 1. 
Table 1

Comparison of Social Media and Instant Messaging Tools Available in Education

\begin{tabular}{|l|l|l|l|l|l|}
\hline & E-mail & SMS & Facebook & Twitter & WhatsApp \\
\hline Price & Free & Collect & Free & Free & $\$ 1$ \\
\hline Usebility & Text size change & Text size change & Limited text & Limited text & Text size change \\
\hline $\begin{array}{l}\text { Creating groups } \\
\text { Adding or removing the } \\
\text { members to the group }\end{array}$ & Possible & Possible & Easy & Not built & Easy \\
\hline Ensuring fluent speech & Not natural & Difficult & Easy & - & Easy \\
\hline $\begin{array}{l}\text { Privacy } \\
\text { private life }\end{array}$ & High & High & Weak & Weak & High \\
\hline $\begin{array}{l}\text { The use of students in } \\
\text { private life }\end{array}$ & Common & High & Uncommon & Uncommon & High \\
\hline Cooperative learning & Uncommon & High & High & Uncommon & High \\
\hline Content sharing & Easy & - & Active & Active & Active \\
\hline
\end{tabular}

\section{Problem}

The aim of this study is to determine the purpose of the communication between the chemistry teachers and their students who communicate through WhatsApp group; and to examine the functions, education, and academic processes in the field of chemistry education as follows:

1. What are the contributions to the education when WhatsApp groups are used as a communication channel between the chemistry teachers and their students?

2. What are the challenges in education when using WhatsApp group as a communication channel between chemistry teachers and their students?

3. What measures have been taken against the problems that arise when the WhatsApp group is used as a communication channel between the chemistry teachers and their students?

\section{Method}

In Turkey, any study in the field of education conducted on the WhatsApp groups used by both the chemistry teachers and their students for the classroom communication have not been reached. Accordingly, the aim of the study and research questions were determined. In order to examine the research questions, interviews were conducted, and thus, qualitative research method was used. Qualitative research provides a picture of a particular individual, group, situation, or problem (Frankel \& Wallen, 1996). Qualitative research is carried out to determine the subjects, phenomena, or perceptions in their natural environment. Interview, observation, and document analysis techniques are generally used in qualitative research (Ekiz, 2003; Kuş, 2003; Şimşek \& Yildirim, 2011).

\section{Data Source and Data Collection}

In the study, interviews were conducted with chemistry teachers who communicated with their students by using Whatsapp groups. Snowball sampling, which is one of the purpose-oriented sampling methods, was used. Snowball sampling is a process of establishing the sample as a chain by contacting another individual with the help of an individual especially in the rare cases (Pagano, 1993).

Open-ended questions were preferred in the study. Using such questions prepares the atmosphere for teachers to share their experiences. Teachers answer the open-ended questions by giving fluent expressions 
about the main subject and provide more data (Simşek \& Yildirim, 2003). Eight high school teachers, two of whom were male, were interviewed. For the purpose of this study, semi-structured interviews were conducted with teachers by using WhatsApp. The interviews were started with a brief description of the research, followed by a few personal questions, and when talking about WhatsApp-related questions, the conversation took the form of a conversation and different experiences were shared. While interviewing with teachers, they were asked to share the activities and their experiences in using the WhatsApp group. In addition, teachers were asked to tell their experiences about the advantages and disadvantages of communicating with the students via whatsApp group. A personal interview directive was established prior to the meeting with teachers.

\section{Personal Interview Directive}

The personal interview directive was intended for chemistry teachers who share the materials related to chemistry lesson with students by creating a WhatsApp group. The directive aimed to learn about the experiences, thoughts, and expectations of the chemistry teachers who use the WhatsApp group to share knowledge in the chemistry classes they have taught.

The questionnaire was designed to collect information on the following subjects:

1. Personal information;

2. The school year and duration of the application;

3. Benefits obtained from the application;

4. Difficulties encountered during application;

5. Measures taken against challenges.

The classification of the data was conducted gradually during and after the interviews. In data collection process, in other words, while the interviews were going on, the data were analyzed. Therefore, a continuous development/refinement process was formed during the data collection and the analysis. This caused the process to be active. At the end of the interviews, deciphering was carried out, and then the data was categorized.

\section{Findings}

Two male and six female teachers were interviewed. All of the teachers are high school teachers working in the institutions affiliated to the MNE, who have been appointed as field experts in chemistry/chemical technologies. Chemistry teachers often attend a large number of classes. They are communicating through the WhatsApp application with maximum three or four groups that they create within the classes they enter. Eight teachers reached approximately 300 students. A total of 15 groups shared information through WhatsApp. While four of the teachers started the idea of class group, the other teachers became the members of the groups established by the students. As a result, there were two forms of administration of the WhatsApp groups: One is the groups that the teachers are the admins, the other is the groups in which the admin students turn over the management to the teachers. In the groups created by the students, the teachers explained that they demanded to open the group in their first messages. In the sample we work, teachers manage the groups with different numbers of students depending on the structure of the schools. The characteristics of the teachers and the groups they created are given in Table 2. The professional experience of eight teachers who participated in the study ranged from eight to 12 years, and teachers have bachelor degrees from the Faculties of Education. 
Table 2

Characteristics of the Teachers and Their Groups

\begin{tabular}{lllllll}
\hline Name & Sex & Topic & $\begin{array}{l}\text { Socio-economic } \\
\text { status }\end{array}$ & Group admin & $\begin{array}{l}\text { Whatsapp group } \\
\text { number }\end{array}$ & $\begin{array}{l}\text { The number of the } \\
\text { students in the group }\end{array}$ \\
\hline T1 (SY) & Male & $\begin{array}{l}\text { Homework } \\
\text { Science }\end{array}$ & High & Teacher & 3 & Between 15-20 \\
T2 (FA) & Female & $\begin{array}{l}\text { English scientific } \\
\text { language }\end{array}$ & High & Student & 2 & Less than 15 \\
T3 (İI) & Male & Homework & Low & Student & 1 & 5 \\
T4 (NZ) & Female & Homework & High & Teacher & 1 & Less than 15 \\
T5 (AK) & Female & Homework & Low & Teacher & 1 & Less than 15 \\
T6 (MK) & Female & Science & Low & Teacher & 3 & Between 20-30 \\
T7 (AŞ) & Female & Science & Low & Student & 3 & Less than 15 \\
T8 (KL) & Female & Homework & Low & Student & 1 & Less than 15 \\
\hline
\end{tabular}

\section{Types of Communication}

In the WhatsApp groups reviewed, written expressions and visuals were generally shared while video files and audio files were rarely shared during communication. The students had little use of the voice recording message option and location information. However, they have repeatedly requested to use the option to change the name and the theme picture of the group. They named the groups: "Best class ever", "Genius class", "Scientific youth", "Love of chemistry", "Every form of matter", "Who is chemistry!", or "X teacher is here" (to remind that the teacher is in the group). The teachers and the students used the camera frequently to photograph notebooks and problem solving drafts, ask questions and answer questions (see Figure 1). Teachers have often added webpage links to their posts as learning material.

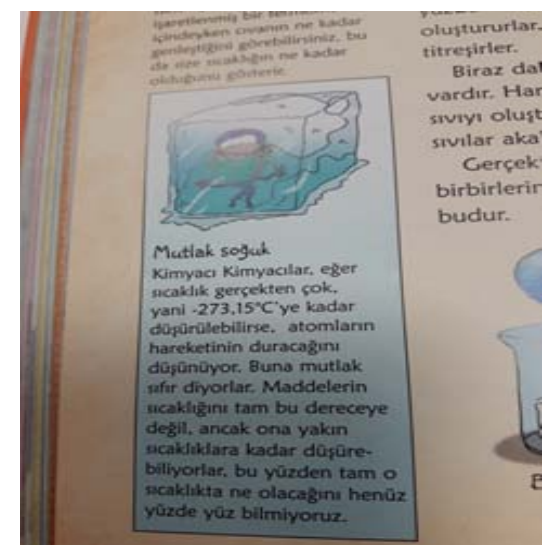

(a) A magazine image related to the subject.

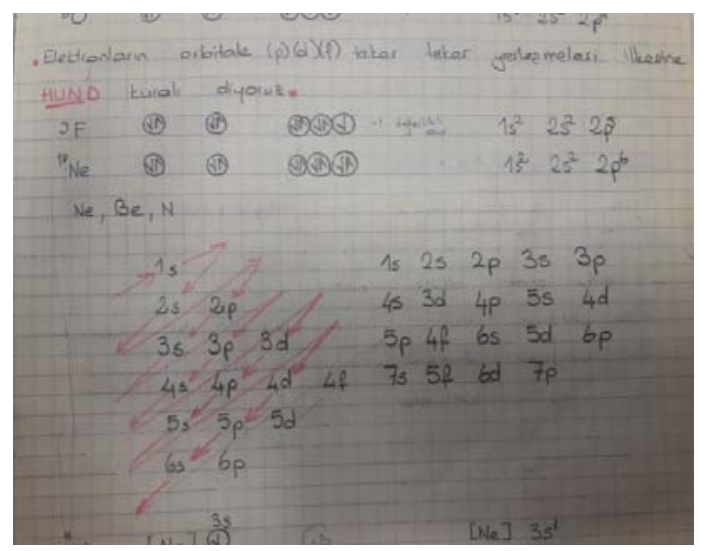

(b) Students' notebook page image.

Figure 1. Communication examples.

\section{Group Creation Objectives}

Teachers formed WhatsApp groups according to their needs. During the interviews with the teachers, the factors in motivating the classes for the formation of the WhatsApp groups were determined. Teachers stated that, before setting up the group, at the beginning of the term, they gave their phone numbers to the students, but the students preferred writing and asking questions via WhatsApp to calling. After a while, the teachers who realized that they answered the same questions a few times started to think that it would be better to set up a group. 
The teachers also explained the benefits of the groups. As a result of the analysis, five main purposes emerged from the repeated statements in the interviews.

Purpose 1: Motivation About the Course. Messages sent through WhatsApp groups help students to create a sense of responsibility by developing a sense of belonging to the class and their friends. Positive social atmosphere is provided. The messages that accelerate the tempo of study to increase the motivation of the students about the course, sending clues about the content of the course, expressions that make them feel the success, messages indicating that their identity and personalities are valuable, the photographs of the moments experienced together were evaluated within the first scope.

Purpose II: Communicating. It helps to communicate with students, to send information, to manage the class, and to feel the students stay in the studying process. Using WhatsApp groups to communicate is advantageous, because it saves time, when one wants to send the message in other ways outside the classroom, communication cannot be achieved in the same way. When they are reminded of the current issues with the messages, the students are interested in the course. It is thought to be very useful to remind students of the things they have to bring events, announcements, and assignments.

Purpose III: Encouraging Information Sharing. WhatsApp groups create an environment that allows students to share information and exchange ideas. It was revealed that, in this environment, students tend to share information, start to help each other, answer each other's questions, and share what they have learned. Information shring content was composed of audio record, problem solution of the problem, and visuals document related to a subject.

Purpose IV: Creating a Learning Environment. Teachers provide learning materials faster and more easily accessible through WhatsApp groups all the time including extracurricular times. WhatsApp group can be used as a learning environment to improve the student's performance with learning activities. The teacher provides the students with the appropriate links where they have difficulty. Students enjoy the chemistry lessons, because they can find what they are looking for more easily in a shorter time from the links (sharing experiment videos they do in the classroom or at home, problem solutions, or the steps of a research). Instant answer given about an unclear topic, related questions and answers were discussed in the opportunity to learn category.

Purpose V: Planning the Study Process. The reminders for students' projects, assignments, and exam dates are made easily with the WhatsApp group. The students are provided with the opportunity to plan the process related to the course and gain the general study habits with the guidance given at the appropriate time. Finally, reminding the deadline for projects and assignments, time for exam preparation. Giving feedback were evaiuated within the process planning.

The purposes of the teachers for setting up a WhatsApp group can be seen in Table 3.

The teachers expressed that there are positive and negative aspects of using WhatsApp together with students. The positive and negative aspects of creating WhatsApp group in scientific communication in the classroom are listed under three headings as technical, educational, and academic in Table 4.

WhatsApp is a simple application in terms of use. Since the teachers and the students use WhatsApp in daily life frequently, using it in educational activities did not overstrain the students. Because the students check every message on their mobile devices with pleasure all day, they said that they read each message immediately if they do not have Internet connection problems. For example, if the teacher tried to communicate with the students via e-mail, the students would not have access to their e-mails every day, so the information 
would not be available on time and effective communication would be impossible. The cost of the text message prevents the students from joining the communication, and the fact that each message has a certain fee causes the student to hesitate to reply a message. T2, T3, and T7 coded teachers stated that they created short message service (SMS is a text messaging service component of most telephone Internet and mobile-device systems) groups to enhance communication in the previous years and sent messages for special occasions, such as birthdays, journeys, and ilnesses, but none of the students participated in this communication even though they were invited to.

Table 3

The Purposes (Main and Secondary Purposes) of the Teachers for Setting up a Whatsapp Group

\begin{tabular}{|l|l|l|l|l|l|l|l|l|}
\hline Purpose & T1 (SY) & T2 (FA) & T3 (ï) & T4 (NZ) & T5 (AK) & T6 (MK) & T7 (AŞ) & T8 (KL) \\
\hline $\begin{array}{l}\text { Motivation about the } \\
\text { course }\end{array}$ & Main & & & & Main & & Main & Main \\
\hline $\begin{array}{l}\text { To strengthen the } \\
\text { communication }\end{array}$ & Secondary & & Main & & Main & Secondary & & Main \\
\hline $\begin{array}{l}\text { To encourage } \\
\text { information sharing }\end{array}$ & & Secondary & & Secondary & & Secondary & & \\
\hline $\begin{array}{l}\text { Learning } \\
\text { environment }\end{array}$ & Main & & Main & & Main & Main & \\
\hline $\begin{array}{l}\text { To plan the study } \\
\text { process }\end{array}$ & Main & & Main & & & & Secondary & Secondary \\
\hline
\end{tabular}

Table 4

Positive and Negative Aspects of Using Whatsapp Group in Technical, Educational, and Academic Terms

\begin{tabular}{|c|c|c|}
\hline & Positive aspects & Negative aspects \\
\hline 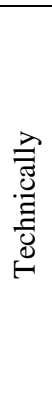 & $\begin{array}{l}\text { Simple; } \\
\text { Free; } \\
\text { Impeccable solution to communicate in case of emergency; } \\
\text { Protection of privacy; } \\
\text { No intervention from outside; } \\
\text { Teachers common use in their daily lives; } \\
\text { Ability to transmit a new idea that comes to mind by voice } \\
\text { recording instantly; } \\
\text { Faster than e-mail; } \\
\text { More successful in communication than text message; } \\
\text { Better course communication tool than Facebook. }\end{array}$ & $\begin{array}{l}\text { When students do not have a smart phone; } \\
\text { When students have no right to use the Internet; } \\
\text { When too many messages are received. }\end{array}$ \\
\hline 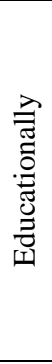 & $\begin{array}{l}\text { Providing to get to know students more closely; } \\
\text { Creating a social environment; } \\
\text { Creating a sense of belonging with those shared in the group; } \\
\text { Forming a communication environment with an appropriate } \\
\text { scientific language among students; } \\
\text { Students' helping each other; } \\
\text { Sharing educational materials with each other (A note in } \\
\text { notebook, a solution of a problem, or a question which could } \\
\text { not be solved); } \\
\text { Strengthening the relationship between teacher and students. }\end{array}$ & $\begin{array}{l}\text { Expectation of students from teachers is high; } \\
\text { Students' not knowing their boundaries (not using } \\
\text { appropriate language); } \\
\text { In some cases, getting involved in all correspondence } \\
\text { between students. }\end{array}$ \\
\hline 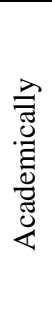 & $\begin{array}{l}\text { Providing easy access to materials for those who want to } \\
\text { learn (giving tips, sharing resources or URL adresses) } \\
\text { Easy access to the teacher; } \\
\text { Opportunity to be able to share a question/ problem/opinion } \\
\text { no matter when and where; } \\
\text { Possibility for instant correction of errors; } \\
\text { Safe environment (The teacher's being in the group provides } \\
\text { control). }\end{array}$ & $\begin{array}{l}\text { Students may not spend enough effort to learn; } \\
\text { Students may ignore the question/message sent by the } \\
\text { teacher; } \\
\text { The academic boundary between the teacher and the } \\
\text { students may be eliminated; } \\
\text { Using the wrong scientific language or missing the } \\
\text { correction may cause incorrect learning; } \\
\text { If the teacher misses the error in the answer given by } \\
\text { the student, the misconception may occur. }\end{array}$ \\
\hline
\end{tabular}


When the teachers compared the SMS group to WhatsApp group, they stated that "SMS group was limited between me and my student, but the coziness provided by the WhatsApp group is different".

Chemistry teachers wanted to communicate with their students via Facebook. Two teachers said that they were not successful in communication on the Facebook group. T2 and T6 coded teachers stated that the information flow was very slow compared to the WhatsApp. They expressed that they spent a lot of time and effort to find, load, and add new content, announcements, questions, and answers about the units. T6 coded chemistry teacher also added that,

There were students from different classes who wanted to become a member of our Facebook group to benefit from these materials, whenever I rejected those demands my students felt concerned, in order to keep the discipline WhatsApp is certainly much beter.

As a result, in class communication, the WhatsApp application is more advantageous for teachers than other communication tools and social networks.

T1 coded teacher said that,

I feel emotionally closer to my students during the lessons and I realized that there are many differences in the fulfillment of the responsibilities of the students. I understand more easily what makes students uncomfortable and they are able to understand me better.

T4 coded teacher expressed that,

Creating the WhatsApp group helped me to get to know the students better, I had a 9th grade group and I can say that having good communication with me at their new school made chemistry class their favorite course. The students who expressed that they did not like the science lesson in the secondary school participated in all the activities in the classroom and after school vigorously. A positive social environment was created in the classroom, I can say that corresponding with me through WhatsApp increased students' self-confidence. The messages which were irrelevant questions at the beginning turned out to be science-centered conversation in a short time. They started to share scientific news from newspapers and other media related to the units we studied in the classroom, which was very pleasing for me, because every year, students start high schools in a way more prone to social areas. It is very good to feel having a scientific communication with them.

Having a WhatsApp group is noticed to affect the positive atmosphere in the classroom.

To T6 coded teacher,

The group was very lively, the idea of having fun and being together was at the center. The students uploaded funny visuals, they needed such a support, I felt compelled to make the education entertaining. The group gave them a sense of belonging. They wanted to be a part of the group. Even the troublesome students participated in the conversations in a positive way, because they knew that if they had an inappropriate share, I would get them out of the group, and the could not take the chance, they wanted to stay in the group and in that environment.

Being a member of the WhatsApp groups seem to strenghten contact with the class and even the feelings towards chemistry lesson. Furthermore, it was generally stated by the teachers that teacher's being a member of the group changed the writing style of the students in a positive way.

T4 coded teacher told that,

I know that students sometimes become very rude, they may not know the speech proprieties. I want to tell an event once I experienced, the students wrote their personal messages to each other once in the group, I saw the message at that moment and took the advantage of being the admin and deleted the message. I called and warned the student, they did not repeat that but I was really concerned at that moment. However, they are more careful when sending a message after that event. 
T5 coded teacher said that,

I understood that the students quell the feeling of loneliness by phone messages, for that reason, they wanted to send messages even during the semester break. For example, during the semester break, the students shared information and helped each other for chemistry course, which made me very happy. The students are underestimating themselves and think that they do not learn sufficiently but they feel that they can be beneficial when they help someone with the information they have.

T7 coded teacher stated that,

Even when a student asked a question directly to me, the other students answered it without giving me the time to answer. And I was correcting the deficiencies. Or I sent reminders, such as "Time for assignments is up", “... days for the exam", or "Did you finish the project?". The reminders of the students are often included in the group discussions. The majority of the class was doing the given task, I never heard that they forgot to do the task. In fact, this is a tradition. Students often forget to do homework.

T2 code teacher shared that,

When I told the 12th grade students that I would abrogate the group at the end of the term, they all objected. They wanted to keep in touch and they still send organic chemistry related links and visuals as well as the good news.

In the academic sense, the expressions of the teachers about the benefits of using WhatsApp can be summarized as follows. The WhatsApp allows students to easily and quickly access to educational materials sent after school hours. Teachers' immediate access to students' questions makes the learning process more productive and ensures the continuity of the group. For example, an exercise or a question, which is sent by the teacher through WhatsApp out of school hours, reaches all the students at the same time. In the same way, the answers of the questions or the clues for the solutions sent by the students in the form of a photograph of the notebook are received by each student instantly. This is thought to have a positive effect on the learning process. Teachers also said that their presence in the WhatsApp groups causes students to feel more secure. The fact that even the students who are hesitant to ask questions in the classroom are able to ask questions or share their answers in the group is academically positive.

T3 coded teacher stated that,

I realized that the students we did not notice in the classroom gave the correct answers to the questions in the WhatsApp group and I only realized then that they were active. As I was thinking that they are unreceptive, their sharing their good ideas in the group made me realize them. Students' individual performances are better understood.

T2 coded teacher said that,

WhatsApp group expanded the learning verge out of school. For instance, when I asked them to do physical chemical change experiments at home, the students recorded different stages of the experiment and uploaded them to the group, which let the others see the videos. When a students did this, the others wished to do the same, and the number of the students doing the experiment suddenly increased. Furthermore, even if I cannot write in any case, transmitting an audio recording very quickly is an advantage of the application and it impresses the students. They say, "Aaa, the teacher is interested in what I do".

T3 coded teacher expressed that,

My students come to school under difficult circumstances and some of them rarely do their homework. When I created the group, I first uploaded a riddle or question and my students showed a lot of interest. This approach inclined the students to do the tasks in the chemistry textbook at home and to get additional information after a while. For example, 
when I send a question before the exam, the students started to ask for more questions after answering the question, they were very eager. Of course, this takes time. When a student asks a question, another student answers, and if there is a mistake, it is very important to correct it immediately, otherwise the opposite can happen.

The challenges of using WhatsApp group for the teachers were also dealt during the interviews. The main challenge is that not all the students have a smartphone. T3 and T7 coded teachers stated that,

If there are students lack of a smart phone, you will not be able to use WhatsApp in the classroom, because we cannot grieve any students or leave them in a difficult situation.

Teachers also complained about the messages sometimes sent by the students late at night. Teachers found solutions when there were such problems. For example, some teachers silenced the notification signal while some others informed the students about the time periods for reading and responding the messages. When the rules were determined by the teachers and the students together, the use of WhatsApp group did not cause any problem. However, T2 coded teacher said that, "You may not know what the rules should be without experiencing the problem, you learn as you experience problems”.

The $\mathrm{T} 5$ coded teacher warned that,

It was very irritating to witness conversations inappropriate for an education environment. For example, a student had an inappropriate correspondence with another student, and I excluded him from the group. After this event, the students were very careful.

She also stated that she wanted to cancel the WhatsApp group due to that misbehaviour of the student, but because the students promised to be mindful, they continued to use the group. All the teachers agreed that the groups could cause problems at the beginning, but it is efficient when the continuity of the system is achieved.

One of the important challenges is that they are worried about not being able to notice the scientific mistakes of the students. They stated that if there is a mistake or a misunderstanding during the course, they are able to correct it and go on the course, but it is difficult to manage that in the digital environment.

\section{Conclusions}

The WhatsApp application is a useful educational technology tool that carries learning beyond the classroom and the school. In this study, interviews with the teachers, who use WhatsApp to communicate in the teaching process of chemistry courses, were analyzed. The positive and negative aspects of using WhatsApp in chemistry education were dealt technically, educationally, and academically.

Today, as distinct from other communication tools, being free of charge, user friendly, accessible and having the opportunity to send voice recording, images, and documents to all members very quickly are the features agreed to make WhatsApp application preferable for chemistry teachers.

It was determined that teachers using WhatsApp were focused on at least five goals. These objectives are: communicating with students, having a positive atmosphere, creating a sense of belonging to the class, creating dialogue, and using the learning platform and sharing.

All of the chemistry teachers started the group with only one or two goals at the beginning, but they realized that the groups also fulfilled other purposes. Teachers did not realize that they were serving at other goals while trying to achieve their own goals. The teachers did not share their experiences on this application with other teachers. They did not feel the need to share their experiences, because they thought that no other teacher performed such a practice. One of the results of this study is that it will be beneficial for branch 
teachers to share experiences by creating a WhatsApp group among themselves in solving problems and planning better practices.

Since the teachers and students commonly use WhatsApp in their daily life they preferred to use it in class communication. In particular, it was very practical for teachers to send voice recordings. The number of students with smart phones is increasing day by day, and the teachers working in schools with low socio-economic status laid emphasis on that students attach great importance to the model of their phones. Five of the chemistry teachers who participated in this research work in schools with low socio-economic status. In this study, the teachers' statements revealed that using the WhatsApp application in chemistry education has several advantages and disadvantages.

WhatsApp groups lead students to use scientific expressions in discussions, to share their video recordings of the experiments they do at home, and to make their personal qualities easier to be noticed. They also help teacher-student communication out of school, provide students with a reliable social atmosphere in digital environment, and cause a positive attitude towards the course as well as a sense of belonging. However, receiving messages at unearthly hours, inappropriate language of the students, the responsibility of following all the correspondence among the students and checking the possible scientific mistakes are the challenges of the practice. Besides, all these require the teacher to allocate time out of working hours.

Chemistry teachers found their own solutions to the problems they face in time. From an academic point of view, some students may not gain the ability to study independently even at high school level. In the WhatsApp application, the help from the classmates for the assignments of the course and the guidance of the teacher enables the students to feel that they can achieve in chemistry lesson. With this application, the ability to access information, content, support, and personal assistance regularly increases the students' learning will and potential.

\section{Suggestions}

According to the results of the study, this application supports the learning process in the traditional classroom, encourages cooperative learning, and provides active participation. It is thought that using WhatsApp application in classrooms for specific purposes will help students to develop 21st century skills. It will enable the development of communication skills, the use of information and communication technologies, and develop problem-solving skills based on these skills. So, studies which investigate how to develop those skills by using WhatsApp are suggested to be conducted.

If WhatsApp is accepted as a common educational tool in the classroom for both teachers and students, further research in more areas will be needed. This study can also be conducted at the universities for specific courses.

The fact that chemistry teachers working in this field can create groups among themselves, communicate and share their problems and good examples will increase the success of the practice.

In this study, the opinions of the chemistry teachers who created WhatsApp groups for their classes were taken, there are students on the other side of such a study. Therefore, it is recommended to evaluate the students' point of views by interviewing with students. Educators can use applications like WhatsApp to create a discussion environment with students, distribute and share the course content as a support for formal education (Conejar \& Kim, 2014). In addition, enriching the messages with texts, audios, and videos supports teachers' teaching practice and the evaluation of students as well as contributing to the learning process of students (Jones et al., 2010; Goodyear et al., 2004). 


\section{References}

Conejar, R. J., \& Kim, H. K. (2014). The effect of the future mobile learning: Current state and future opportunities. International Journal of Software Engineering and Its Applications, 8(8), 193-200.

Dan Bouhnik, D., \& Deshen, M. (2014). WhatsApp goes to school: Mobile instant messaging between teachers and students. Journal of Information Technology Education Research, 13, 217-231.

Demirel, Ö. (2016). New directions in education. Pegem Citation Index, (5), 1-312.

Ekiz, D. (2003). Introduction to research methods and methods in education: Qualitative, quantitative and critical theory methodologies. Ani Yayincilik.

Fraenkel, J. R., \& Wallen, N. E. (1996). Valididity and reliability: How to design and research in education (Vol. 3, pp. 153-171). New York: McGraw-Hill, INC.

Goodyear, P., Banks, S., Hodgson, V., \& McConnell, D. (Eds.). (2004). Research on networkedlearning: An overview. In Advances in research on networked learning. Dordrecht: Springer.

Güven, Z. Z. (2016). The journey of information technologies on the tomorrow in English teaching. In E. Yilmaz, M. Çalişkan, and S. A. Sulak (Eds.), Reflections from education science (pp. 201-212). Konya: Çizgi Kitabevi.

Jones, N., Blackey, H., Fitzgibbon, K., \& Chew, E. (2010). Get out of my space! Computers \& Education, 54, 776-782.

Kirschner, P. A., \& Karpinski, A. C. (2010). Facebook and academic performance. Computers in Human Behavior, 26(6), 1237-1245.

Kulesza, J., DeHondt, I. I. G., \& Nezlek, G. (2011). More technology, less learning. Information Systems Education Journal, 9(7), 4-13.

Kuş, E. (2003). Quantitative-qualitative research techniques. Ankara: Ani Yayincilik.

Pagano, M. (1993). Gauvreau: Sampling theory (pp. 469-472). Belmont: Duxbury Press.

Santarosa, C., \& Castillo, J. (2017). What's up in the classroom? Whatsapp! Retrieved November 3, 2017, from https://ltsig.iatefl.org/whats-up-in-the-classroom-whatsapp/

Şimşek, H., \& Yildirim, A. (2011). Qualitative research methods in the social sciences. Ankara: Seçkin Yayincilik.

Şimşek, H., \& Yildirim, A. (2003). Qualitative research methods in the social sciences. Ankara: Seçkin Yayincilik.

Turaç, N., Çalişkan, N., \& Gülnar, E. (2017). Comparison of mastery learning model and WhatsApp assisted learning in teaching psychomotor skills: A triangulation study. Journal of Human Sciences, 14(3), 2601-2615.

Whatsapp. (2017). Retrieved September 18, 2017, from https://www.whatsapp.com/about/

Whatsapp Period in Education. (2017). Retrieved September 18, 2017, from http://www.hurriyet.com.tr/egitimde-whatsappdonemi-40044865

Yener, O., \& Gül, A. (2007). Population-sampling issue on social and educational research studies. Kazım Karabekir Eğitim Fakültesi Dergisi, (15), 394-422.

Zan, N. (2015). The effects of smartphone use on organic chemical compound learning. US-China Education Review A, 5(2), 105-113.

Zan, N., Zan, B. U., \& Morgil, İ. (2014, June). Effects of smartphones, in naming of chemical compounds. Paper presented at The World Conference on Educational Multimedia, Hypermedia and Telecommunications, Tampere, Finland. 